\title{
HUBUNGAN BEBERAPA INDIKATOR OBESITAS DENGAN TEKANAN DARAH WANITA DEWASA MUDA
}

\author{
Anak Agung Ayu Fuji Dwi Astuti, Nurmasari Widyastuti, Aryu Candra*) \\ ${ }^{*}$ Departemen Ilmu Gizi Fakultas Kedokteran Universitas Diponegoro \\ Jln. Prof. H. Soedarto, SH., Semarang, Telp (024) 8453708, Email : gizifk@ undip.ac.id
}

\begin{abstract}
Background: An increase in blood pressure $(B P)$ is associated with overweight and obesity. Anthropometric measurement can be used to define obesity, such as waist to hip ratio (WHR), waist to height ratio (WtHR), body mass index (BMI), waist circumference (WC) and recently developed "A Body Shape Index" (ABSI).

Objective: To examine the association between obesity indicators and BP in early adult women.

Methods: A cross sectional study in district work Local Goverment Clinic Kedung Mundu of women aged 18-21 years was selected by consecutive sampling. The measured anthropometric were height, body mass, WC and hip circumference and BP. Data were analyzed by Fisher Exact and consideration prevalens ratio to estimated risk.

Result: There are 9,4\% women with pre hypertension. Overweight and obesity based on BMI 28,1\%. High risk based on WC 6\%, WHR 62,5\%, WtHR 29,7\% and ABSI 50\%. BMI is significantly related to SBP (p<0,05, RP6,3, CI $1,038 \pm 38,056)$. WC is significantly related to DBP ( $p<0,05, R P 6,3, C I 1,038 \pm 38,056)$. WHR, WtHR and ABSI were not significantly related to both $S B P$ and $D B P(p>0,05)$.

Conclusion: BMI is associated with SBP. WC is associated with DBP. However, WRH, WtHR and ABSI do not associated with $S B P$ and DBP.

Keywords: Blood pressure, obesity indicator, obesity
\end{abstract}

\begin{abstract}
ABSTRAK
Latar Belakang: Peningkatan tekanan darah (TD) berhubungan dengan kelebihan berat badan dan obesitas. Obesitas dapat ditentukan melalui pengukuran antropometri seperti rasio lingkar pinggang terhadap lingkar panggul (RLPP), lingkar pinggang terhadap tinggi badan (RLPTB), indeks massa tubuh (IMT), lingkar pinggang (LiPi) dan baru-baru ini dikembangkan "A Body Shape Index" (ABSI).

Tujuan: Menganalisis hubungan beberapa indikator obesitas dengan TD pada wanita dewasa muda.

Metode: Studi cross sectional di wilayah kerja Puskesmas Kedung Mundu pada 64 wanita usia 18-21 tahun yang dipilih secara consecutive sampling. Pengukuran antropometri meliputi tinggi badan, berat badan, lingkar pinggang dan panggul dan TD. Data dianalisis dengan uji Fisher Exact dan perhitungan rasio prevalensi untuk mengetahui besar risiko.

Hasil: Terdapat 9,4\% wanita mengalami pre hipertensi. Gizi lebih berdasarkan IMT 28,1\%. Resiko tinggi berdasarkan LiPi 6\%, RLPP 62,5\%, RLPTB 29,7\% dan ABSI 50\%. Terdapat hubungan signifikan antara IMT dengan TDS ( $p<0,05$,

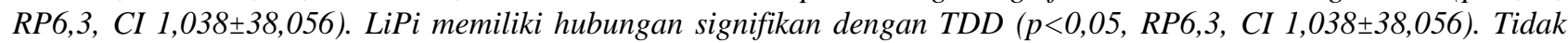
terdapat hubungan antara RLPP, RLPTB dan ABSI dengan TDS dan TDD $(p>0,05)$.

Simpulan: IMT berhubungan dengan TDS. LiPi berhubungan dengan TDD. Tidak terdapat hubungan antara RLPP, RLPTB dan ABSI dengan TDS dan TDD.
\end{abstract}

Kata kunci: Tekanan darah, indikator obesitas, obesitas

\section{PENDAHULUAN}

Hipertensi atau tekanan darah tinggi merupakan salah satu Penyakit Tidak Menular (PTM) yang saat ini menjadi masalah kesehatan yang cukup serius, disebut sebagai silent killer. ${ }^{1}$ Hipertensi yang tidak terkontrol dan terdeteksi sejak dini dapat menyebabkan peningkatan risiko berbagai penyakit degeneratif seperti serangan jantung, stroke, dan gagal ginjal. ${ }^{2}$

Masalah hipertensi di Indonesia cenderung mengalami peningkatan. Berdasarkan data Riskesdas 2013 prevalensi hipertensi berdasarkan wawancara mengalami peningkatan dari 7,6\% pada tahun 2007 menjadi $9,5 \%$ pada tahun 2013 dan hipertensi lebih banyak terjadi pada perempuan yaitu $28,8 \%$ sedangkan laki-laki 22,8\%. ${ }^{3}$ Hipertensi di Kota Semarang pada tahun 2015 merupakan penyakit tidak menular yang menempati peringkat tertinggi dengan angka kejadian sebesar 29.335 kasus $^{4}$, sementara prevalensi hipertensi pada usia 18-24 tahun berkisar pada $7,7 \%^{1}$, dan hipertensi pada kelompok usia $>18$ tahun di Jawa Tengah sendiri berkisar pada $26,4 \%$ pada daerah perkotaan. ${ }^{4}$

Terdapat berbagai faktor risiko yang mempengaruhi terjadinya peningkatan tekanan darah, salah satunya adalah kelebihan berat badan. Penilaian status gizi melalui pemeriksaan antropometri dapat digunakan untuk menilai kelebihan berat badan dan kondisi obesitas. Indikator status gizi yang dikaitkan dengan tekanan darah antara lain Indeks Massa 
Tubuh (IMT), Lingkar Pinggang (LiPi), Rasio Lingkar Pinggang Terhadap Lingkar Panggul (RLPP), Rasio Lingkar Pinggang Terhadap Tinggi Badan (RLPTB) dan A Body Shape Index (ABSI) atau dengan kata lain sering disebut sebagai indikator penentuan obesitas. IMT memiliki hubungan yang kuat dengan tekanan darah. Peningkatan IMT berhubungan erat dengan tekanan darah dimana kejadian hipertensi lebih tinggi pada orang dengan IMT yang lebih besar. ${ }^{5}$ Pertambahan LiPi berhubungan erat dengan kejadian kardiovaskuler ${ }^{6}$, pada perempuan lingkar pinggang sebesar $\leq 80 \mathrm{~cm}$ berisiko rendah dan risiko tinggi apabila $\geq 88 \mathrm{~cm}$. RLPP dapat digunakan untuk mengukur timbunan lemak tubuh terutama daerah abdomen. RLPP $\geq 0,85$ pada wanita mempunyai risiko 8 kali lebih besar untuk menderita hipertensi dibandingkan dengan yang memiliki RLPP normal. ${ }^{7}$ RLPTB merupakan indeks antropometri yang baik untuk mengidentifikasi risiko penyakit kardio-metabolik pada orang dewasa normal ataupun overweight. ${ }^{8}$ Terdapat korelasi positif antara nilai ABSI dengan persebaran jaringan adiposa pada daerah abdominal. ${ }^{9}$

Berdasarkan laporan Profil Kesehatan Kota Semarang, wilayah kerja Puskesmas Kedung Mundu merupakan salah satu wilayah dengan prevalensi hipertensi tertinggi di Kota Semarang. Penelitian ini dilaksanakan di wilayah kerja Puskesmas Kedung Mundu dengan harapan banyak wanita yang mengalami peningkatan tekanan darah melebihi batas normal dan hipertensi. Penelitian ini bertujuan untuk mengetahui indikator status gizi, dalam hal ini indikator obesitas yang berpengaruh terhadap tekanan darah wanita dewasa muda usia 18-21 tahun.

\section{METODE}

Penelitian ini merupakan penelitian deskriptif analitik dengan metode cross-sectional, termasuk lingkup penelitian gizi masyarakat. Pengambilan data dilakukan pada bulan FebruariApril 2017. Kriteria inklusi sampel penelitian yaitu perempuan berusia 18-21 tahun, bersedia mengisi informed consent, tidak dalam kondisi sakit, tidak merokok, tidak mengonsumsi alkohol, tidak mengonsumsi obat-obatan yang berpengaruh terhadap tekanan darah, IMT $\geq 18,50 \mathrm{~kg} / \mathrm{m}^{2}$ dan dapat berkomunikasi dengan baik. Berdasarkan perhitungan sampel yang telah dilakukan dibutuhkan sampel minimal 60 orang. Jumlah sampel didapatkan sebanyak 64 orang wanita usia 18-21 tahun, dipilih secara consecutive sampling di kelurahan Sambiroto, Sendangmulyo dan Sendangguwo. Sampel yang terpilih bersedia mengikuti penelitian dan hadir pada waktu pengambilan data.

Variabel bebas (independen) dalam penelitian ini adalah Indeks Massa Tubuh (IMT),
Lingkar Pinggang (LiPi), Rasio Lingkar Pinggang Panggul (RLPP), Rasio Lingkar Pinggang Tinggi Badan (RLPTB) dan A Body Shape Index (ABSI), sedangkan variabel terikat (dependen) adalah tekanan darah. Data yang dikumpulkan antara lain identitas sampel, berat badan (BB), tinggi badan (TB), LiPi, RLPTB, ABSI, tekanan darah sistolik (TDS), dan tekanan darah diastolik (TDD).

Tekanan darah diukur dengan menggunakan sphygmomanometer air raksa. Data akhir yang dipakai adalah rata-rata dua kali pengukuran, kemudian data dikategorikan tidak hipertensi jika TDS $<120$ dan TDD $<80$ dan pre hipertensi jika TDS $\geq 120$ dan TDD $\geq 80$ mmHg. ${ }^{10}$ IMT didefinisikan sebagai indeks yang diperoleh dari pengukuran $\mathrm{BB}$ dengan menggunakan timbangan injak digital (kapasitas $150 \mathrm{~kg}$, ketelitian $0,1 \mathrm{~kg}$ ) dan pengukuran $\mathrm{TB}$ dengan menggunakan microtoise (kapasitas $200 \mathrm{~cm}$, ketelitian $0,1 \mathrm{~cm}$ ) yang dihitung menggunakan rumus berat badan $(\mathrm{kg})$ dibagi dengan kuadrat tinggi badan (m). IMT kemudian dikategorikan gizi baik dengan IMT $\leq 22,90 \mathrm{~kg} / \mathrm{m}^{2}$ dan gizi lebih $\geq 23,00 \mathrm{~kg} / \mathrm{m}^{2}$.

Lingkar pinggang diukur melalui lingkar pertengahan garis antara tepi inferior costa (tulang iga) terbawah dan crista iliaca (bagian lateral sebelah atas tulang panggul). Subjek yang diukur berada dalam posisi berdiri pada saat akhir ekspirasi. ${ }^{11}$ Lingkar panggul diukur pada lingkaran paling maksimal dari gluteal pada bidang horizontal. Pengukuran lingkar pinggang dan panggul menggunakan pita ukur midline (kapasitas $150 \mathrm{~cm}$, ketelitian $0,1 \mathrm{~cm})$.

Data lingkar pinggang kemudian dikategorikan risiko rendah peningkatan tekanan darah jika $\leq 88 \mathrm{~cm}$ dan risiko tinggi apabila $\geq 88 \mathrm{~cm} .{ }^{12}$ RLPP diperoleh dari pembagian lingkar pinggang dengan lingkar panggul, dikategorikan $<0,8$ risiko rendah peningkatan tekanan darah jika dan $>0,8$ risiko tinggi. RLPTB diperoleh dari pembagian lingkar pinggang dengan tinggi badan, dikategorikan risiko rendah peningkatan tekanan darah jika $<0,5$ dan risiko tinggi $>0,5$. ABSI didefinisikan sebagai indeks yang diperoleh melalui rumus lingkar pinggang dalam meter $(\mathrm{m})$ dibagi dengan perkalian IMT $\left(\mathrm{kg} / \mathrm{m}^{2}\right)$ dalam pangkat $2 / 3$ dan tinggi badan (m) dalam pangkat 1/2. ${ }^{13}$ ABSI dikategorikan berdasarkan z-score, dibagi menjadi dua kelompok, risiko rendah peningkatan tekanan darah jika $<-0,272$, sedang-tinggi jika $-0,272$ sampai dengan $>+0,229$.

Analisis data menggunakan software statistik. Analisis univariat dilakukan untuk mendeskripsikan masing-masing variabel. Analisis bivariat dilakukan untuk melihat hubungan masingmasing variabel independen dengan variabel 
dependen menggunakan uji Fisher Exact, kemudian besar risiko dilihat berdasarkan rasio prevalens.

\section{HASIL PENELITIAN}

Subjek pada penelitian ini berjumlah 64 orang wanita berusia 18-21 tahun. Rata-rata umur wanita $18,97 \pm 0,89$. Prevalensi pre hipertensi wanita sebesar 9,4\% berdasarkan TDS, 28,1\% berdasarkan TDD dan 9,4\% berdasarkan keduanya. Terdapat $28,1 \%$ wanita yang mengalami gizi lebih berdasarkan IMT. Hal ini secara rinci terdapat pada tabel 1 dan 2.

Tabel 1. Karakteristik dan distribusi frekuensi subjek

\begin{tabular}{|c|c|c|c|c|c|c|}
\hline \multirow{2}{*}{ Variabel } & \multicolumn{3}{|c|}{ Wanita $(n=64)$} & \multirow{2}{*}{ Distribusi } & \multicolumn{2}{|c|}{ Wanita $(n=64)$} \\
\hline & Min. & Maks. & Rerata \pm SD & & $\mathbf{n}$ & $\%$ \\
\hline Umur (th) & 18 & 21 & $18,97 \pm 0,89$ & & & \\
\hline BB (kg) & 34,80 & 78,10 & $52,23 \pm 7,76$ & & & \\
\hline TB $(\mathrm{kg})$ & 132,00 & 165,00 & $153,94 \pm 5,63$ & & & \\
\hline \multirow[t]{2}{*}{$\operatorname{IMT}\left(\mathrm{kg} / \mathrm{m}^{2}\right)$} & 18,60 & 31,22 & $22,12 \pm 3,01$ & Gizi Baik & 46 & 71,9 \\
\hline & & & & Gizi Lebih & 18 & 28,1 \\
\hline \multirow[t]{2}{*}{$\mathrm{LiPi}(\mathrm{cm})$} & 61,00 & 104,00 & $74,73 \pm 9,40$ & Risiko Rendah & 58 & 90,6 \\
\hline & & & & Risiko Tinggi & 6 & 9,4 \\
\hline \multirow[t]{2}{*}{ RLPP } & 0,71 & 0,96 & $0,82 \pm 0,06$ & Risiko Rendah & 24 & 37,5 \\
\hline & & & & Risiko Tinggi & 40 & 62,5 \\
\hline \multirow[t]{2}{*}{ RLPTB } & 0,39 & 0,68 & $0,48 \pm 0,06$ & Risiko Rendah & 45 & 70,3 \\
\hline & & & & Risiko Tinggi & 19 & 29,7 \\
\hline \multirow[t]{2}{*}{ ABSIz } & $-3,4947$ & 2,0186 & $-0,23 \pm 1,26$ & Risiko Rendah & 32 & 50,0 \\
\hline & & & & Risiko Sedang-Tinggi & 32 & 50,0 \\
\hline \multirow[t]{2}{*}{ TDS } & 90 & 120 & $104,22 \pm 8,82$ & Normal & 58 & 90,6 \\
\hline & & & & Pre hipertensi & 6 & 9,4 \\
\hline \multirow[t]{2}{*}{ TDD } & 60 & 90 & $72,27 \pm 7,28$ & Normal & 46 & 71,9 \\
\hline & & & & Pre hipertensi & 18 & 28,1 \\
\hline
\end{tabular}

BB, berat badan; TB, tinggi badan; IMT, indeks massa tubuh; LiPi, lingkar pinggang; RLPP, rasio lingkar pinggang terhadap lingkar panggul; RLPTB, rasio lingkar pinggang terhadap tinggi badan; ABSIz, A Body Shape Index z score; TDS, tekanan darah sistolik; TDD, tekanan darah diastolik.

Hasil analisis bivariat menunjukkan bahwa terdapat hubungan yang signifikan antara indikator obesitas IMT dengan TDS dan indikator obesitas LiPi dengan TDD, $p$ value $<0,05$, namun tidak terdapat hubungan antara indikator obesitas LiPi, RLPP, RLPTB dan ABSIz dengan TDS dan IMT, RLPP, RLPTB, dan ABSIz dengan TDD. Hasil secara rinci terdapat pada tabel 2 dan 3 .

Tabel 2. Hasil analisis bivariat Fisher Exact Indikator Obesitas dengan Tekanan Darah Sistolik

\begin{tabular}{|c|c|c|c|c|c|c|}
\hline \multirow[t]{3}{*}{ Variabel } & \multicolumn{2}{|c|}{ Tekanan Darah Sistolik } & \multirow{3}{*}{$p$} & \multirow{3}{*}{$\mathbf{R P}$} & \multirow{2}{*}{\multicolumn{2}{|c|}{$95 \% \mathrm{CI}$}} \\
\hline & \multirow{2}{*}{$\begin{array}{c}\text { Normal } \\
\mathbf{n}(\%)\end{array}$} & \multirow{2}{*}{$\begin{array}{c}\text { Prehipertensi } \\
\text { n }(\%)\end{array}$} & & & & \\
\hline & & & & & Lower & Upper \\
\hline IMT & & & & & & \\
\hline Gizi Baik & $44(68,8)$ & $2(3,1)$ & $0,048^{\mathrm{a}}$ & 6,286 & 1,038 & 38,056 \\
\hline Gizi Lebih & $14(21,9)$ & $4(6,2)$ & & & & \\
\hline LiPi & & & & & & \\
\hline Resiko Rendah & $54(84,4)$ & $4(6,2)$ & $0,093^{\mathrm{a}}$ & 6,750 & 0,934 & 48,792 \\
\hline Resiko Tinggi & $4(6,2)$ & $2(3,1)$ & & & & \\
\hline RLPP & & & & & & \\
\hline Resiko Rendah & $23(35,9)$ & $1(1,6)$ & $0,397^{\mathrm{a}}$ & 3,286 & 0,360 & 29,968 \\
\hline Resiko Tinggi & $35(54,7)$ & $5(7,8)$ & & & & \\
\hline RLPTB & & & & & & \\
\hline Resiko Rendah & $42(65,6)$ & $3(4,7)$ & $0,351^{\mathrm{a}}$ & 2,625 & 0,479 & 14,380 \\
\hline Resiko Tinggi & $16(25,0)$ & $3(4,7)$ & & & & \\
\hline ABSIz & & & & & & \\
\hline Resiko Rendah & $30(46,9)$ & $2(3,1)$ & $0,672^{\mathrm{a}}$ & 2,143 & 0,364 & 12,628 \\
\hline Resiko Sedang-Tinggi & $28(43,8)$ & $4(6,2)$ & & & & \\
\hline
\end{tabular}


Tabel 3. Hasil analisis bivariat Fisher Exact Indikator Obesitas dengan Tekanan Darah Diastolik

\begin{tabular}{|c|c|c|c|c|c|c|}
\hline \multirow[t]{3}{*}{ Variabel } & \multicolumn{2}{|c|}{ Tekanan Darah Diastolik } & \multirow{3}{*}{$p$} & \multirow{3}{*}{$\mathbf{R P}$} & \multirow{2}{*}{\multicolumn{2}{|c|}{$95 \% \mathrm{CI}$}} \\
\hline & \multirow{2}{*}{$\begin{array}{c}\text { Normal } \\
\mathrm{n}(\%) \\
\end{array}$} & \multirow{2}{*}{$\begin{array}{c}\text { Prehipertensi } \\
\text { n }(\%) \\
\end{array}$} & & & & \\
\hline & & & & & Lower & Upper \\
\hline IMT & & & & & & \\
\hline Gizi Baik & $36(56,2)$ & $10(15,6)$ & $0,120^{\mathrm{a}}$ & 2,880 & 0,899 & 9,225 \\
\hline Gizi Lebih & $10(15,6)$ & $8(12,5)$ & & & & \\
\hline LiPi & & & & & & \\
\hline Resiko Rendah & $44(68,8)$ & $14(21,9)$ & $0,048^{a}$ & 6,286 & 1,038 & 38,056 \\
\hline Resiko Tinggi & $2(3,1)$ & $4(6,2)$ & & & & \\
\hline RLPP & & & & & & \\
\hline Resiko Rendah & $18(28,1)$ & $6(9,4)$ & $0,778^{\mathrm{a}}$ & 1,286 & 0,409 & 4,040 \\
\hline Resiko Tinggi & $28(43,8)$ & $12(18,8)$ & & & & \\
\hline RLPTB & & & & & & \\
\hline Resiko Rendah & $34(53,1)$ & $11(17,2)$ & $0,368^{\mathrm{a}}$ & 1,803 & 0,569 & 5,716 \\
\hline Resiko Tinggi & $12(18,8)$ & $7(10,9)$ & & & & \\
\hline ABSIz & & & & & & \\
\hline Resiko Rendah & $25(39,1)$ & $7(10,9)$ & $0,405^{\mathrm{a}}$ & 1,871 & 0,616 & 5,683 \\
\hline Resiko Sedang-Tinggi & $21(32,8)$ & $11(17,2)$ & & & & \\
\hline
\end{tabular}

\section{PEMBAHASAN}

Terdapat keterkaitan antara kondisi obesitas dengan peningkatan tekanan darah. Berat badan berlebih dikaitkan dengan peningkatan kadar insulin dalam darah. Peningkatan insulin ini berkaitan dengan retensi natrium dan air sehingga menyebabkan volume darah meningkatan. Volume darah yang meningkat akan meningkatkan curah jantung dan berdampak pada peningkatan tekanan darah dan terjadinya hipertensi. Peningkatan berat badan juga dikaitkan dengan peningkatan penumpukan plak pada arteri dan mengakibatkan saluran arteri menyempit. Penyempitan arteri ini menjadikan aliran darah meningkat dan memerlukan peningkatan dorongan untuk memompa darah ke seluruh tubuh. Peningkatan dorongan ini dapat berperan pada kenaikan tekanan darah. ${ }^{14}$ Kondisi kelebihan berat badan dan obesitas juga menyebabkan terjadinya hiperaktivitas saraf simpatis sehingga terjadi vasokonstriksi sistemik dan meningkatkan denyut jantung, hal ini mengakibatkan tekanan darah meningkat. ${ }^{15}$

Pengukuran antropometri merupakan salah satu cara yang digunakan dalam penentuan status gizi termasuk kondisi kelebihan berat badan dan obesitas. Pengukuran antropometri sendiri telah banyak digunakan dalam berbagai penelitian epidemiologi karena penggunaannya yang sederhana. ${ }^{16}$ Indikator status gizi yang sering dipakai sebagai indikator obesitas umumnya digunakan dalam skrining awal resiko berbagai penyakit degeneratif pada populasi skala besar.

Penelitian ini dilakukan pada subjek wanita dewasa muda dengan usia 18-21 tahun yang merupakan bagian dari rentang usia dewasa muda yaitu 17-25 tahun. Penelitian ini menemukan kejadian pre hipertensi sebesar 9,4\% berdasarkan TDS, 28,1\% berdasarkan TDD dan 9,4\% berdasarkan keduanya, namun tidak ditemukan kejadian hipertensi pada saat pengambilan sampel. Hal ini mungkin dapat disebabkan karena pada dasarnya usia dewasa muda memang belum banyak yang menderita hipertensi terutama pada perempuan. Penelitian ini juga menemukan kejadian gizi lebih (kategori kelebihan berat badan dan obesitas) sebanyak $28,1 \%$ berdasarkan IMT $\geq 23 \mathrm{~kg} / \mathrm{m}^{2}$.

\section{Hubungan IMT dengan Tekanan Darah}

Indikator obesitas IMT merupakan cara yang paling umum digunakan untuk memperkirakan obesitas, berkorelasi tinggi dengan massa lemak tubuh dan penting untuk mengidentifikasi orang obesitas yang mempunyai resiko mengalami komplikasi medis. ${ }^{17}$ Keunggulan utama dari IMT ini adalah mampu menggambarkan kelebihan berat badan, sederhana dan dapat digunakan dalam penelitian populasi skala besar. Uji statistik menunjukkan terdapat hubungan bermakna antara IMT dengan TDS $(p<0,05)$, namun tidak terdapat hubungan bermakna dengan TDD $(p>0,05)$. Hal ini berbeda dengan penelitian yang dilakukan di Medan, dimana IMT berhubungan dengan TDS dan TDD $(\mathrm{p}<0,05) .{ }^{18}$ Hasil uji statistik juga menunjukkan bahwa wanita dengan IMT lebih besar berisiko 6 kali mengalami peningkatan TDS dan 3 kali peningkatan TDD. Perbedaan signifikansi antara TDS dan TDD ini mungkin disebabkan karena perbedaan sampel antara kedua penelitian yang dilakukan.

\section{Hubungan Lingkar Pinggang dengan Tekanan Darah}

Penelitian pada individu Jordania menemukan bahwa lingkar pinggang merupakan prediktor independen dari kejadian hipertensi dengan 
subjek berusia diatas 18 tahun. ${ }^{19}$ Uji statistik menunjukkan tidak terdapat hubungan bermakna LiPi dengan TDS $(p>0,05)$, namun terdapat hubungan bermakna dengan TDD $(p<0,05)$. Hal ini berbeda dengan penelitian yang dilakukan pada subjek dewasa laki-laki dan perempuan dimana LiPi berkorelasi dengan TDS $(\mathrm{p}=0,01)$ pada perempuan namun tidak berkorelasi dengan TDD $(p>0,05)$. Perbedaan hasil dari kedua penelitian ini kemungkinan disebabkan oleh adanya perbedaan usia sampel yang diteliti. Penelitian ini menggunakan sampel perempuan usia 18-21 tahun sejumlah 64 orang sedangkan penelitian tersebut menggunakan sampel usia 25-45 tahun. ${ }^{20}$ Hasil uji statistik juga menunjukkan wanita dengan LiPi lebih besar berisiko 7 kali mengalami peningkatan TDS dan 6 kali peningkatan TDD.

Lingkar pinggang merupakan salah satu parameter yang dapat digunakan untuk menilai akumulasi lemak pada daerah abdomen. Akumulasi lemak pada abdomen, yang memberi bentuk tubuh menyerupai apel disebut dengan obesitas android. Insiden hipertensi cenderung meningkat pada individu dengan obesitas android. Kondisi ini disebabkan karena terjadi peningkatan pelepasan asam lemak bebas sebagai akibat proses lipolisis dan proses lipolisis lemak viseral lebih banyak daripada lipolisis lemak subkutan. Peningkatan lipolisis dari lemak viseral meningkatkan pelepasan asam lemak bebas dalam sirkulasi. Asam lemak bebas yang terlepas akan menuju aliran darah, menyebabkan peningkatan beban koresterol yang membawa lipoprotein, LDL yang dapat beresiko meningkatkan tekanan darah. ${ }^{21}$

\section{Hubungan RLPP dengan Tekanan Darah}

Uji statistik menunjukkan tidak terdapat hubungan bermakna RLPP dengan TDS dan TDD $(p>0,05)$. Hal ini senada dengan penelitian yang dilakukan pada anak usia sekolah dasar yang memperoleh hasil bahwa tidak terdapat hubungan bermakna antara RLPP dengan TDS dan TDD. ${ }^{15}$ Hasil ini berbeda dengan penelitian Savita yang menemukan bahwa terdapat hubungan signifikan antara RLPP dengan tekanan darah pada subjek dewasa dengan hipertensi dan diabetes mellitus. ${ }^{22}$

Pertambahan usia berhubungan dengan perubahan distribusi lemak tubuh dan perubahan distribusi lemak ini tidak selalu dapat langsung terlihat pada pengukuran antropometri termasuk berat badan dan lingkar pinggang. ${ }^{23}$ Selain itu perbedaan sekresi hormon juga dapat mempengaruhi distribusi lemak tubuh seseorang, dimana distribusi lemak yang lebih berkaitan dengan peningkatan tekanan darah adalah distribusi lemak sentral (abdominal) dibandingkan dengan distribusi lemak perifer. ${ }^{15}$ RLPP berhubungan dengan lemak viseral, tetapi
RLPP tidak dapat digunakan untuk memprediksi secara akurat perubahan pada lemak viseral. Hal ini dikarenakan lingkar panggul hanya dipengaruhi lemak subkutan sehingga keakuratan RLPP pada pengukuran lemak visceral menurun dengan meningkatnya lemak subkutan tubuh.

\section{Hubungan RLPTB dengan Tekanan Darah}

RLPTB berdasarkan uji statistik menunjukkan tidak terdapat hubungan bermakna RLPTB dengan TDS dan TDD $(p>0,05)$. Hal ini berkebalikan dengan penelitian yang dilakukan oleh Bejamin dimana terdapat hubungan signifikan antara RLPTB dengan TDS dan TDD $(\mathrm{p}<0,01)$ pada subjek diatas 21 tahun. ${ }^{15}$ Perbedaan hasil dari kedua penelitian ini kemungkinan disebabkan oleh adanya perbedaan usia sampel yang diteliti. Penelitian ini menggunakan sampel perempuan usia 18-21 tahun sedangkan penelitian oleh Bejamin menggunakan sampel usia $>21$ tahun.

Penelitian lain pada anak-anak menemukan bahwa tidak terdapat hubungan signifikan antara RLPTB dengan tekanan darah sistolik. ${ }^{24}$ Grafik pertumbuhan dapat mempengaruhi hasil ukur rasio dari lingkar pinggang dan tinggi badan seseorang. ${ }^{24}$ Usia dewasa muda pertambahan tinggi badan sudah tidak lagi maksimal dibandingkan pada masa-masa remaja, sedangkan lingkar pinggang dapat terus bertambah seiring dengan pertambahan usia, pada perempuan hal ini lebih masif terjadi setelah menopause selain itu terdapat penelitian yang menyebutkan perbedaan jenis kelamin dan tingkat usia berpengaruh terhadap pengukuran RLPTB.

\section{Hubungan ABSI dengan Tekanan Darah}

Uji statistik menunjukkan tidak terdapat hubungan bermakna antara ABSI yang $(p>0,05)$ dengan TDS dan TDD. Hasil ini senada dengan penelitian pada pria yang menemukan bahwa tidak terdapat hubungan bermakna antara ABSI dengan tekanan darah $(\mathrm{p}=0,440) .{ }^{25}$ Bentuk tubuh yang diukur dengan ABSI dinilai dapat menjelaskan resiko kematian lebih besar pada populasi umum. Ada kemungkinan ABSI yang tinggi berhubungan dengan lemak viseral yang berpotensi meningkatkan tekanan darah, namun pada penelitian ini ketika ABSI digunakan untuk memprediksi peningkatan tekanan darah tidak ditemukan hasil serupa dengan penelitian pada remaja dimana ABSI merupakan prediktor yang lebih baik dalam peningkatan tekanan darah dibandingkan IMT dan LiPi. ${ }^{26}$

Kemungkinan terjadi perbedaan hasil diakibatkan oleh perbedaan populasi, pengukuran dasar ABSI yang menggunakan lingkar pinggang dan IMT yang dapat berbeda ditiap etnis dan jumlah sampel yang lebih sedikit dibandingkan penelitian lain yang dilakukan pada remaja. Penelitian lain mengenai ABSI dan tekanan darah yang dilakukan di 
Indonesia namun pada populasi dengan usia lebih tua juga menunjukkan tidak adanya hubungan signifikan antara ABSI dengan tekanan darah. Hal ini mungkin disebabkan pula karena eksponen dalam penyusunan rumus ABSI pada studi aslinya (Amerika) berbeda dengan Indonesia. ${ }^{27}$ Diperlukan penelitian lebih lanjut untuk mengetahui hubungan ABSI dengan tekanan darah, khususnya sebagai prediktor hipertensi. Disisi lain, indeks dari ABSI lebih sulit diterapkan dilapangan dibandingkan dengan indikator obesitas lain yang lebih mudah dan praktis untuk skrining obesitas dengan cepat namun tetap dapat menggambarkan kondisi obesitas.

Pengendalian berat badan dan lingkar pinggang menjadi penting dalam penelitian ini karena berhubungan dengan peningkatan tekanan darah, namun lingkar panggul yang diaplikasikan dalam RLPP meski tidak menunjukkan hasil statistik yang bermakna tetap perlu diperhatikan seperti halnya lingkar pinggang untuk mencegah akumulasi lemak berlebihan pada daerah abdominal. Penelitian ini menemukan bahwa TDD yang tidak normal lebih banyak dibandingkan TDS yaitu sebanyak 18 orang $(28,1 \%)$. Selain peningkatan tekanan darah sistolik, peningkatan tekanan darah diastolik juga perlu diwaspadai.

Umumnya peningkatan tekanan darah diastolik ini terjadi pada anak-anak dan dewasa muda. Hal ini dapat menyebabkan terjadinya penyakit yang dikenal dengan "isolated diastolic hypertension" atau IDH, dimana tekanan darah diastolik meningkat tanpa diikuti peningkatan tekanan darah sistolik. Kondisi IDH lebih jarang terjadi dibandingkan dengan ISH (isolated systolic hypertension), namun peningkatan tekanan darah diastolik juga dapat membahayakan karena menyebabkan gangguan pada jantung, otak dan ginjal. ${ }^{28,29}$

Seperti yang telah diketahui bahwa dalam sebuah penelitian terdapat berbagai faktor yang dapat mempengaruhi hasil dari penelitian, pada penelitian ini keterbatasan penelitian yang dialami adalah pengambilan sampel menggunakan metode consecutive sampling sehingga dapat menyebabkan sampel yang diambil tidak mewakili keseluruhan populasi yang ada. Selain itu kesalahan dalam pengukuran tekanan darah dan antropometri juga mempengaruhi hasil penelitian.

\section{SIMPULAN}

Prevalensi pre hipertensi wanita usia 18-21 tahun sebesar 9,4\%. Wanita beresiko berdasarkan IMT 28,1\%, LiPi 9,4\%, RLPP 62,5\%, RLPTB 29,7\% dan ABSIz 50,0\%. Indikator obesitas IMT berhubungan dengan TDS dan indikator obesitas LiPi berhubungan dengan TDD. Prevalensi pre hipertensi lebih tinggi pada TDD sebesar $28,1 \%$.

\section{SARAN}

Untuk mencegah terjadinya hipertensi pada wanita dewasa muda perlu dilakukan pengendalian berat badan dan menjaga ukuran lingkar pinggang tetap dalam batas ideal. Penentuan status gizi melalui pengukuran antropometri IMT dan lingkar pinggang dapat dijadikan sebagai indikator obesitas untuk memprediksi risiko hipertensi.

Pertimbangan kembali penggunaan ABSI sebagai indikator obesitas untuk memprediksi risiko hipertensi perlu dilakukan karena penerapan dari indikator ini yang lebih rumit dibandingkan dengan indikator lainnya sehingga lebih sulit diterapkan dilapangan.

\section{UCAPAN TERIMAKASIH}

Terimakasih disampaikan kepada seluruh responden dan enumerator yang terlibat dalam penelitian atas kerjasama selama penelitian ini berlangsung serta semua pihak yang telah memberikan dukungan selama ini.

\section{DAFTAR PUSTAKA}

1. Rahajeng E, Tuminah S. Prevalensi Hipertensi dan Determinannya di Indonesia. 2009; 59 (12): 580-586.

2. Theodore A, Kotchen JM. Nutrition, Diet, and Hypertension. In: Shils Me. Modern Nutrition In Health And Disease Tenth Edition. Philadephia: Lipponcott Williams And Wilkins; 206.P.1095-102.

3. Departemen Kesehatan. Riset Kesehatan Dasar 2013. Jakarta: Depkes RI; 2013. P. 5.

4. Dinas Kesehatan Kota Semarang. Profil Kesehatan Kota Semarang 2015. Semarang: Dinkes Kota Semarang; 2015. P. 56-58.

5. Humayun A, Shah AS, Sultana R. Relation of Hypertension with Body Mass Index And Age in Male and Female Population of Peshawar, Pakistan.J Ayub Med Coll Abbottabad. 2009;21(3):63-5.

6. Supariasa I, Bakri B, Fajar I. Penilaian Status Gizi. Jakarta: Buku Kedokteran EGC, 2012. P. 59-60.

7. Esa K. Besar Risiko Rasio Lingkar Pinggang Pinggul dan Asupan Natrium terhadap Kejadian Hipertensi [Skripsi]. Semarang: Universitas Diponegoro; 2006.

8. Hsieh SD, Yoshinaga H, Muto T. Waist-To-Height Ratio, A Simple and Practical Index for Assessing Central Fat Distribution and Metabolic Risk in Japanesse Men and Women. Int J Obes Relat Metab Disord. 2003; 27(5):610-6.

9. Dhana K, Koolhas C, Schoufour J, Rivadeneira F, Hofman A, Kavousi M, et al. Association of Anthropometric Measures with Fat and Fat-Free Mass in The Elderly: The Rotterdam Study. Maturitas 2016;88:96-100.

10. Houston, Mark C. Handbook Of Hypertension. UK: Wiley-Blackwell; 2009. P. 23.

11. Seidell JC, Visscher TL. Aspek Kesehatan Masyarakat pada Gizi Lebih. In: Gibney MJ, Margetts BM, Kearney JM, Arab L, Editors. Gizi Kesehatan Masyarakat. Jakarta: EGC; 2009. P. 204. 
12. Meredith S, Madden AM. Categorisation of Health Risk Associated with Excessive Body Weight Identified Using Body Mass Index , A Body Shape Index and Waist Circumference. 2014;4: 185-186.

13. Krakauer NY, Krakauer JC. A New Body Shape Index Predicts Mortality Hazard Independently of Body Mass Index. Plos One. 2012; 7 (7): E39504.

14. Kardi E. Hidup Bersama Penyakit Hipertensi, Asam Urat, Jantung Koroner. Jakarta: Intisari Mediatama; 2002. P. 1-42.

15. Romdhonah R. Hubungan Antara Beberapa Indikator Obesitas dengan Tekanan Darah pada Anak Usia Sekolah [Skripsi]. Semarang: Universitas Diponegoro. 2008.

16. Chang Y, Guo X, Li T, Li S, Guo J, Sun Y. A Body Shape Index and Body Roundness Index: Two New Body Indices to Identify Left Ventricular Hypertrophy Among Rural Populations In Northeast China. Hear. Lung Circ. 2016;25:358-364.

17. Utari A. Hubungan Indeks Massa Tubuh dengan Tingkat Kesegaran Jasmani pada Anak Usia 12-14 Tahun [Tesis]. Semarang: Universitas Diponegoro; 2007.

18. D Sarah A, Tjipta GD. Hubungan Indeks Massa Tubuh dengan Tekanan Darah Anak di Sekolah Dasar Negeri 064979 Medan. E-Jurnal FK USU. 2013; 1(1): 1-4.

19. Batiha A, Alazzam M, Albashtawy M, Tawalbeh L, Tubaishat A, Alhalaiqa FN. The Relationship Between Hypertension and Anthropometric Indices In A Jordanian Population. 2015;7(5): 233-243.

20. Oviyanti PN. Hubungan Antara Lingkar Pinggang dan Rasio Lingkar Pinggang Panggul dengan Tekanan Darah pada Subjek Usia Dewasa [Skripsi]. Surakarta: Universitas Sebelas Maret; 2010.

21. Sidartawan S. Obesitas . Dalam: Aru W. Sudoyo, dkk. Buku Ajar Ilmu Penyakit Dalam jilid III edisi IV. Jakarta: Pusat Penerbitan Departemen Ilmu Penyakit Dalam FK UI; 2006. p. 1941-47.

22. Patil SS, Rajaram DR, BS Nandakumar, Seeri JS. Correlation of Waist Hip Ratio and BMI with Hypertension and Diabetes Mellitus in an Urban Area of Bangalore City. National Journal of Community Medicine. 2015;6(1):82-85.

23. Cheong KC, Ghazali SM, Hock LK, Subenthiran S, Huey TC, Kuay LK, et al. The Discriminative Ability of Waist Circumference, Body Mass Index And Waist-To-Hip Ratio in Identifying Metabolic Syndrome: Variations by Age, Sex and Race. Diabetes Metab. Syndr. Clin. Res. Rev. 2015;9(2):7478.

24. Whitrow MJ, Moore VM, Davies MJ. Waist-toHeight Ratio is not a Predictor of Systolic Blood Pressure in 3-Year-Old Children. J. Pediatr. 2011;159(3):501-503.

25. Bayu HE. Perbedaan A Body Shape Index dan Body Mass Index sebagai Prediktor Hipertensi pada PNS Pria Kantor Wilayah Direktorat Jenderal Pajak Kalimantan Barat di Pontianak [Skripsi]. Pontianak: Universitas Tanjung Pura; 2014.

26. Duncan MJ, Mota J, Vale S, Santos MP, Ribeiro JC. Associations Between Body Mass Index, Waist
Circumference and Body Shape Index With Resting Blood Pressure In Portuguese Adolescents. Annals Of Human Biology. 2013; 40(2): 163-167.

27. Cheung YB. "A Body Shape Index" In Middle-Age and Older Indonesian Population: Scaling Exponents and Association with Incident Hypertension. Plos One. 2013; 9(1): E85421.

28. Wang Y, Xing F, Liu R, Liu L, Zhu Y, Wen Y, et al. Isolated Diastolic Hypertension Associated Risk Factors Among Chinese In Anhui Province, China. International Journal of Environmental Research And Public Health. 2015; 12: 4395-4405.

29. Franklin SS. The Importance of Diastolic Blood Pressure In Predicting Cardiovascular Risk. Journal Of The American Society Of Hypertension. 2007; 1(1): 82-93. 